\title{
A novel UPLC-PDA isocratic method for the quantification fulvestrant in oil-based pre- filled syringe injection matrix formulations
}

\author{
Thirupathi Dongala ${ }^{1,2}$, Ashok Kumar Palakurthi ${ }^{1}$, Yashodharani Vytla ${ }^{1}$ and Naresh Kumar Katari ${ }^{2^{*}}$
}

\begin{abstract}
Background: Fulvestrant is a new estrogen receptor antagonist available in the market globally for the treatment of hormone receptor-positive metastatic breast cancer in postmenopausal women.

Methods: The chromatographic separation of fulvestrant was carried out by using ACQUITY UPLC and a BEH Shield RP18, $50 \mathrm{~mm} \times 2.1 \mathrm{~mm}$, i.d 1.7- $\mu \mathrm{m}$ column with a prepared mobile phase consisting of water, acetonitrile, and methanol in the ratio of 300:400:300 ( $/ / \mathrm{v} / \mathrm{V})$, respectively. $1.0 \mathrm{~mL}$ orthophosphoric acid was added to the prepared mobile phase. The wavelength for detection was made at $220.0 \mathrm{~nm}$ using a PDA-UV detector with a flow rate of $0.3 \mathrm{~mL} \min ^{-} 1$.

Results: The system suitability parameters were found within the limits. The coefficient of correlation was found not less than 0.999 . The percent recoveries of fulvestrant from 80,100 , to $120 \%$ levels are $100.1,100.4$, and 99.7 respectively. The LOD $\left(0.51 \mu \mathrm{g} \mathrm{mL}^{-1}\right)$ and LOQ $\left(1.54 \mu \mathrm{g} \mathrm{mL}^{-1}\right)$ values from the study demonstrate that the method is sensitive. The samples were subjected to forced degradation conditions of acidic and alkaline hydrolysis, oxidation, photolysis, metallic and thermal degradation in all conditions; peak was found pure (purity angle less than that of threshold).

Conclusion: A rapid, simple, stability-indicating, and validated RP-UPLC method was developed with 6 min of run time for the quantification of fulvestrant in oil-based injection formulations. This is the first stability-indicating method with the capability of resolving all the fulvestrant degradation impurities in the drug products. The method was validated for system suitability, linearity, precision, accuracy, specificity, intermediate precision, ruggedness, robustness, and solution stability.
\end{abstract}

Keywords: Fulvestrant, Method development, Validation, UPLC method, Stability indicating, Injections

\section{Background}

Fulvestrant,

7-alpha-[9-(4,4,5,5,5-pentamfluoropentylsulphinyl) nonyl]estra-1,3,5-(10)-triene-3,17-beta-diol (Howell et al., 2000) is a new estrogen receptor antagonist available on the market globally for treatment of hormone receptor-positive metastatic breast cancer in postmenopausal women. Fulvestrant, a novel estrogen receptor, has proven to be a safe and effective treatment for advanced breast cancer in women (Bowler, Lilley, Pittam, \& Wakeling, 1989; Morris, \& Wakeling, 2002; Bundred, \& Howell,

\footnotetext{
* Correspondence: dr.n.k.katari@gmail.com

${ }^{2}$ Department of Chemistry, GITAM University, Hyderabad, Telangana 502329, India

Full list of author information is available at the end of the article
}

2002). The drug is formulated as an oily matrix and is administered as a long-acting intramuscular injection.

Fulvestrant is an estrogen receptor antagonist with no known agonist effects; its mechanism of action works by downregulating the estrogen receptor (Robertson et al., 1996; Brunner et al., 1994). It has a unique mode of action that offers the potential for continued hormonal treatment in patients (Wakeling et al., 1993).

Currently, breast cancer is the most common cancer in women across the globe. The majority of breast cancers are estrogen receptor (ER) positive, and the frequency of ER-positive tumors is highest among older women. Various clinical studies have been published in the literature about cancer treatment. 
Fulvestrant has poor solubility in the aqueous medium and has been developed as an extended release drug. Fulvestrant injection prepared in an oil-based formulation is recommended once monthly as an intramuscular injection. Several research articles describing the pharmacology and pharmacokinetics of fulvestrant have been published (Addo et al., 2002; Bogliolo et al., 2016; Bross et al., 2002; Buzdar \& Robertson et al., 2006; Di Leo et al., 2010; Dodwell \& Vergote et al., 2005; Harrison et al., 2003), but very little information regarding its analytical methodology is available (Osborne et al., 2004; Robertson \& Harrison et al., 2004; Robertson et al., 2003; Vergote \& Abram et al., 2006; Varanasi et al., 2010). High-performance liquid chromatography and electrospray tandem mass spectrometry methods for the determination of fulvestrant in rabbit plasma have reported the sample preparation by liquid-liquid extraction; neither the robustness study nor the impurity elution and forced degradation (FD) conditions were reported. Furthermore, this method cannot be used for the finished product analysis in the quality control lab. The proposed method is a stability-indicating ultra-performance liquid chromatogra phy-photodiode array detector (UPLC-PDA) method for the determination of fulvestrant in oil-based injection formulations in the quality control lab.

In the quality control department for pharmaceutical products, the identification and quantification of a drug substance and impurities in the drug product are very important for quality, safety, and efficacy. The impurities and possible potent degradation byproducts which may be present in the pharmaceutical drug substance and drug products may change their chemical, toxicological, and pharmacological properties, affecting the stability.

Therefore, this paper describes a new UPLC stability-indicating method for the determination of fulvestrant in oil-based injections. The UPLC method was developed to demonstrate the utility of UV-PDA (ultraviolet) detection for the determination of fulvestrant with simple sample preparation and reasonable analysis time with high precision. Moreover, the present work describes the possible degradation pathways of fulvestrant under acidic, alkaline, peroxide, thermal, humidity, metallic, and photostability conditions. Also, the present work describes, for the first time, the development and validation of a stability-indicating UPLC method for stability evaluation and quantitative determination of fulvestrant in the presence of its degradation products. Stability-indicating methods are traditionally developed using gradient elution, but the current method was developed with isocratic elution, ensuring that all possible degradants are well resolved from the fulvestrant peak. The proposed method was developed and validated by using the ultra-performance liquid chromatography for the extraction and separation of the fulvestrant from oil matrix and from the major impurities respectively (Fig. 1), within $6 \mathrm{~min}$ of run time.

\section{Methods}

\section{Chemical and reagents}

Fulvestrant standard was obtained from Aurex Laboratories LLC. Methanol (purity 99.9\%) and acetonitrile (99.9\%) (HPLC grade) were procured from RANKEM, RFCL limited, New Delhi, India. High-purity water was taken from an Evoqua water purification system. Orthophosphoric acid (OPA purity 85\%), AR grade, was procured from Central Drug House (p) Limited, New Delhi, India. Fulvestrant impurities were purchased from Veeprho laboratories Pvt. Ltd., Talegaon Dabhade, Pune, Maharashtra, India. Other chemicals used were of analytical or HPLC grade.

\section{Analytical conditions}

The Waters ACQUITY UPLC H-Class was used consisting of a quaternary solvent manager, a sample manager, and a photodiode array UV detector. The output signal was monitored and processed using Empower 3 software. The UPLC separation was carried out on an ACQUITY UPLC; a BEH Shield RP18, $50 \mathrm{~mm} \times 2.1 \mathrm{~mm}$, i.d $1.7-\mu \mathrm{m}$ column was used as a stationary point maintained at ambient temperature with a flow rate of 0.3 $\mathrm{mL} \mathrm{min}^{-1}$. The mobile phase consists of water, acetonitrile, and methanol in the ratio of 300:400:300 $(v / v / v)$, respectively. $1.0 \mathrm{~mL}$ orthophosphoric acid solution was added, then filtered through a $0.45-\mu \mathrm{m}$ PTFE filter and degassed in an ultrasonicator for about $15 \mathrm{~min}$ prior to use. The wavelength for detection of compounds was made at $220.0 \mathrm{~nm}$ using PDA; injection volume was $3.0 \mu \mathrm{L}$.

\section{Preparation of diluent}

One hundred percent methanol was selected as a diluent throughout the experiments. All the solutions and solvents were sonicated and filtered through $0.45-\mu \mathrm{m}$ membrane filters prior to the analysis.

\section{Preparation of standard}

Standard solutions were prepared by dissolving the drug in the diluent to get the desired concentration. Methanol was used as a solvent system. Accurately weighed $50 \mathrm{mg}$ of fulvestrant (99.3\%) was transferred into a $100-\mathrm{mL}$ volumetric flask and dissolved in the diluent. $5.0 \mathrm{~mL}$ of stock solution was pipetted into a $25-\mathrm{mL}$ volumetric flask and diluted with a diluent to get a solution of $100 \mu \mathrm{g} \mathrm{mL}^{-1}$.

\section{Preparation of sample}

The method was used for quantification of Faslodex 250 $\mathrm{mg} / \mathrm{mL}$ PFs (pre-filled syringes). Two pre-filled syringes were pooled into a beaker. About $1 \mathrm{~g}$ (equivalent to 50 mg of fulvestrant) pooled sample was weighed and transferred into a $100-\mathrm{mL}$ volumetric flask. About $70 \mathrm{~mL}$ 


\begin{tabular}{|c|c|c|c|c|}
\hline S.No. & $\begin{array}{l}\text { Impurity } \\
\text { Name }\end{array}$ & IUPAC Name & $\begin{array}{c}\text { Molecular } \\
\text { Weight }\end{array}$ & Structure \\
\hline 1 & Fulvestrant & $\begin{array}{l}(7 \alpha, 17 \beta)-7-[9-[4,4,5,5,5- \\
\text { Pentafluoropentyl)sulfinyl]nonyl]estra- } \\
\text { 1,3,5(10)-triene-3,17-diol }\end{array}$ & 606.77 & \\
\hline 2 & $\begin{array}{c}\text { 6-Keto } \\
\text { Fulvestrant }\end{array}$ & $\begin{array}{l}\text { Estra-1,3,5(10)-triene-6-one-3,17- } \\
\text { diol,7-[9-[(4,4,5,5,5-penta } \\
\text { fluoropentyl) sulfinyl]nonyl]-(7 } \alpha, 17 \beta)\end{array}$ & 620.75 & \\
\hline 3 & $\begin{array}{l}\text { Delta }(6,7) \\
\text { Fulvestrant }\end{array}$ & $\begin{array}{l}\text { 7-[9-[(4,4,5,5,5- } \\
\text { Pentafluoropentyl)sulfinyl]nonyl]estra- } \\
\text { 1,3,5(10),6-tetraene-3,17 } \beta \text {-diol }\end{array}$ & 604.75 & \\
\hline 4 & $\begin{array}{l}\text { Fulvestrant } \\
\text { 9-Sulfone }\end{array}$ & $\begin{array}{l}\text { Estra-1,3,5(10)-triene-3,17-diol,7-[9- } \\
{[(4,4,5,5,5-\text { pentafluoropentyl)sulfonyl] }} \\
\text { nonyl]-( } 7 \alpha, 17 \beta)\end{array}$ & 622.77 & \\
\hline 5 & $\begin{array}{l}\text { Fulvestrant } \\
\text { Extended }\end{array}$ & $\begin{array}{l}\text { 7-[9-[[9-[(4,4,5,5,5- } \\
\text { Pentafluoropentyl)sulfinyl]nonyl]sulfi } \\
\text { nyl]nonyl]estra-1,3,5(10)-triene-3,17ß- } \\
\text { diol }\end{array}$ & 781.07 & \\
\hline 6 & $\begin{array}{c}\text { Fulvestrant } \\
\text { Sterol } \\
\text { Dimer }\end{array}$ & $\begin{array}{l}\text { 7,7'-Nonane-1,9-diylbis[estra- } \\
\text { 1,3,5(10)-triene-3,17ß-diol] }\end{array}$ & 668.99 & \\
\hline
\end{tabular}

Fig. 1 Fulvestrant and its impurity names and chemical structure

diluent was added, and the solution was mixed and sonicated for $15 \mathrm{~min}$. The sample is oily in nature; to get the $100 \%$ extraction, intermediate shaking is required while sonicating. The volume was diluted with a diluent and mixed well (concentration $500 \mu \mathrm{g} \mathrm{mL}$ ). $5.0 \mathrm{~mL}$ of the above solution was pipetted into a $25-\mathrm{mL}$ volumetric flask and diluted to volume with the diluent and mixed well (concentration $100 \mu \mathrm{g} \mathrm{mL}^{-1}$ ).

\section{Forced degradation studies}

Forced degradation (FD) study was performed under different stress conditions to prove the stability-indicating capability of the optimized method. Moreover, it has given information on routes of degradation and formation of degradation byproducts. According to the $\mathrm{ICH}$ guidelines $(\mathrm{ICH}$, Stability testing of new drug substances and products 2005; ICH 2003), stress testing performed with the addition of drug substance and drug product can help identify the likely degradation products, contributing to the definition of the intrinsic stability of the product. FD conditions are usually harsh than accelerated stability testing conditions such as temperature, relative humidity $(>75 \%)$, hydrolysis at high and low $\mathrm{pH}$, and oxidation and photostability. When doing a stress study, the minimum range of degradation of the drug substance is $1-20 \%$. In order to get degradation, the stress condition is increased but not so intense that it generates secondary degradation of products. The stress samples were prepared to obtain a final concentration of $100 \mu \mathrm{g} \mathrm{mL}{ }^{1}$ of fulvestrant. Acid and alkali hydrolysis samples were neutralized prior to the UPLC analysis. In some of the degradation conditions, the peak area of fulvestrant and its possible degradation products was formed. The FD sample assay was performed against a qualified fulvestrant working standard. The peak purity of the FD samples was verified by a PDA-UV detector keeping auto threshold and 200- to 400-nm parameters in the Empower 3 software. 

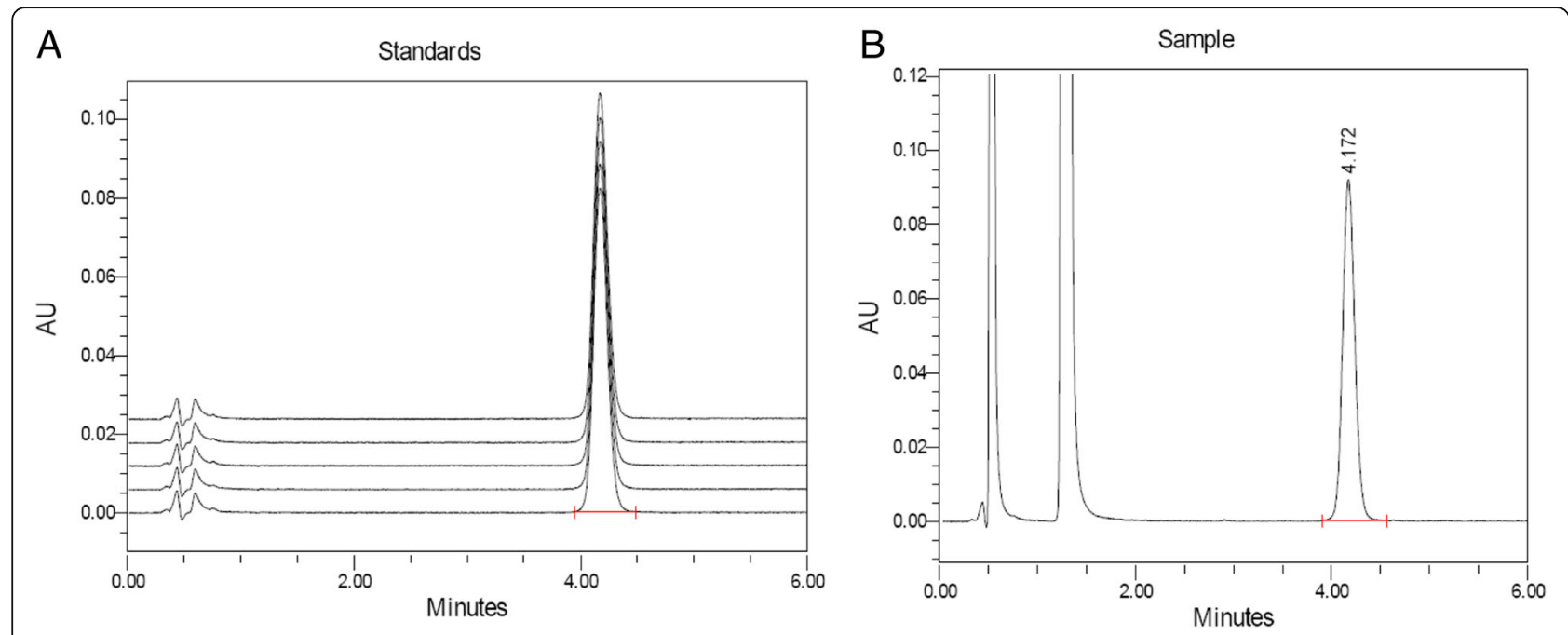

Fig. 2 a Overlaid chromatogram of fulvestrant standard $\left(100 \mu \mathrm{gL}^{-1}\right)$. b Fulvestrant sample chromatogram $\left(100 \mu \mathrm{gL}^{-1}\right)$

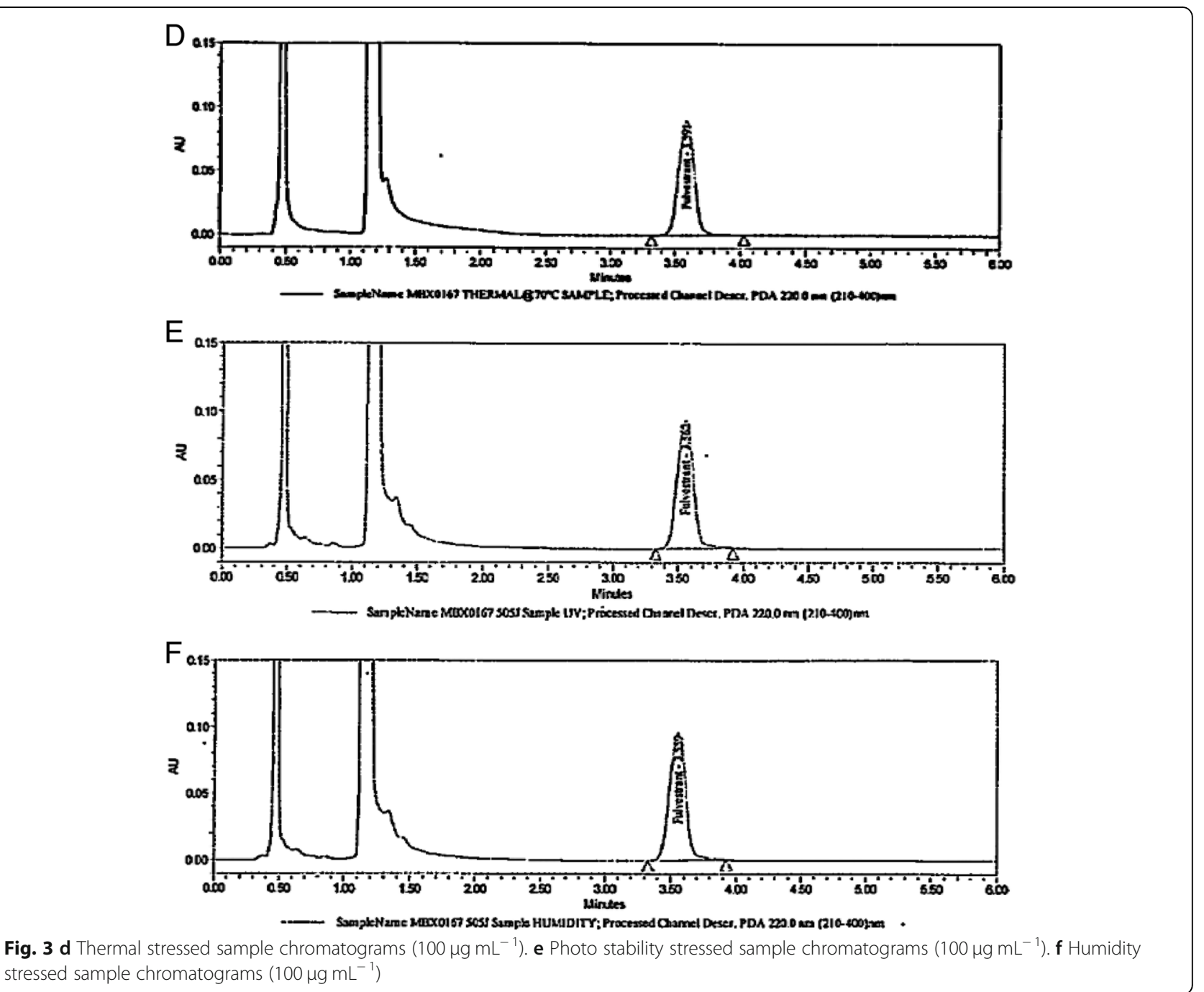


Table 2 Stress conditions for fulvestrant

\begin{tabular}{|c|c|c|c|c|c|}
\hline Nature of stress & Condition & $\%$ Assay of stressed test & Purity angle & Purity threshold & Purity flag \\
\hline Unstressed & NA & 100.4 & 1.991 & 2.948 & NO \\
\hline Acid & 2N HCl@ RT, 18 h & 104.0 & 2.255 & 3.206 & NO \\
\hline Base & 2 N NaOH@ RT, for 18 h & 100.5 & 1.809 & 2.658 & NO \\
\hline Peroxide & $30 \% \mathrm{H}_{2} \mathrm{O}_{2} @ 70{ }^{\circ} \mathrm{C}$, for $18 \mathrm{~h}$ & 102.4 & 2.028 & 3.170 & NO \\
\hline Water & $70^{\circ} \mathrm{C}$ for $18 \mathrm{~h}$ & 91.3 & 2.119 & 3.098 & NO \\
\hline Photolytic & $1200 \mathrm{~W} / \mathrm{m}^{2} 200$ million lux hours & 101.6 & 0.134 & 5.329 & NO \\
\hline Thermal & $70^{\circ} \mathrm{C}$ for $18 \mathrm{~h}$ & 97.0 & 2.060 & 2.985 & NO \\
\hline Humidity & $90 \% \mathrm{RH}$ for 7 days & 102.8 & 0.143 & 5.336 & NO \\
\hline Metallic ion & 0.05 M CuSo4@10min & 99.0 & 0.475 & 8.427 & NO \\
\hline
\end{tabular}

\section{Acid and alkali forced degradation (hydrolytic conditions)} The sample was treated individually with $5 \mathrm{~mL}$ of $2.0 \mathrm{~N}$ $\mathrm{HCl}, 2.0 \mathrm{~N} \mathrm{NaOH}$, and water then kept on a heating water bath at $70{ }^{\circ} \mathrm{C}$ for about $18 \mathrm{~h}$. After the stipulated time, the samples were withdrawn and kept on the bench top to attain room temperature. The solution was neutralized by adjusting the $\mathrm{pH}$ to 7.0 and then diluted to volume with the diluent to obtain a final concentration of $100 \mu \mathrm{g} \mathrm{mL} L^{-1}$.

\section{Hydrogen peroxide-forced degradation (oxidizing conditions)}

The sample was transferred to a $100-\mathrm{mL}$ volumetric flask and $5 \mathrm{~mL}$ of $30 \% \mathrm{H} 2 \mathrm{O} 2$ was added, then kept on the heating water bath at $70^{\circ} \mathrm{C}$ for about $18 \mathrm{~h}$. The samples were withdrawn and kept on the bench top to attain room temperature. The samples were withdrawn and subjected to a UPLC analysis soon after suitable dilution (concentration $100 \mu \mathrm{g} \mathrm{mL}^{-1}$ ).

\section{Thermal degradation}

The sample (direct exposure) was placed in an oven at $70{ }^{\circ} \mathrm{C}$ for $18 \mathrm{~h}$. The heat-exposed sample was transferred to a $100-\mathrm{mL}$ volumetric flask, and the volume was made up to the mark with the diluent and was diluted to volume with the diluent to obtain a final concentration of $100 \mu \mathrm{g} \mathrm{mL}^{-1}$.

\section{Photolytic degradation}

The photolytic stability of the sample was studied by exposing the sample liquid directly to the ultraviolet (UV) and cool white fluorescence (VIS) lamps for 10 days. The overall illumination used was not less than 1.2 million lux hours (VIS) and 200 watt $\mathrm{h} / \mathrm{m}^{2}$ (UV). The exposed sample was transferred to a $100-\mathrm{mL}$ volumetric flask, and the volume was made up to the mark with the diluent and was diluted to volume with the diluent to obtain a final concentration of $100 \mu \mathrm{g} \mathrm{mL}{ }^{-1}$.

\section{Metallic degradation}

The metallic stability of the sample was studied by exposing the sample directly to $0.05 \mathrm{M} \mathrm{CuSO}_{4}$ for about $10 \mathrm{~min}$. The exposed sample was transferred to a $100-\mathrm{mL}$ volumetric flask, and the volume was made up to the mark with the diluent and was diluted to volume with the diluent to obtain a final concentration of $100 \mu \mathrm{g} \mathrm{mL}{ }^{-1}$.

\section{Procedure for method validation}

The optimized chromatographic method was validated by the evaluating system suitability, specificity, linearity, precision, accuracy, limit of detection (LOD), limit of quantification (LOQ), and robustness as per the $\mathrm{ICH}$ validation guidelines.

Table 1 Optimization mobile phase and column in method development

\begin{tabular}{|c|c|c|c|c|}
\hline Trail no. & Mobile phase composition & Column & Observation & Inference \\
\hline 1 & $\begin{array}{l}\text { Monobasic sodium phosphate: } \\
\text { acetonitrile }(60: 40 \mathrm{v} / \mathrm{v})\end{array}$ & $\begin{array}{l}\text { ACQUITY UPLC HSST3 } 100 \\
\mathrm{~mm} \times 1 \mathrm{~mm} 1.8 \mu \mathrm{m}\end{array}$ & $\begin{array}{l}\text { Delta }(6,7) \text { fulvestrant impurity not separated from } \\
\text { fulvestrant }\end{array}$ & $\begin{array}{l}\text { Method } \\
\text { rejected }\end{array}$ \\
\hline 2 & $0.1 \%$ v/v TEA: acetonitrile $(60: 40$ v/v) & $\begin{array}{l}\text { ACQUITY UPLC HSST3 } 100 \\
\mathrm{~mm} \times 1 \mathrm{~mm} 1.8 \mu \mathrm{m}\end{array}$ & Impurities are not separated from fulvestrant peak & $\begin{array}{l}\text { Method } \\
\text { rejected }\end{array}$ \\
\hline 3 & $0.1 \%$ v/v OPA: methanol (600:400 v/v/v) & $\begin{array}{l}\text { ACQUITY UPLC Phenyl } 150 \\
\mathrm{~mm} \times 2.1 \mathrm{~mm} 1.7 \mu \mathrm{m}\end{array}$ & $\begin{array}{l}\text { Impurities are separated from fulvestrant. But sulfone } \\
\text { impurity was eluted very late }\end{array}$ & $\begin{array}{l}\text { Method } \\
\text { rejected }\end{array}$ \\
\hline 4 & $\begin{array}{l}\text { 0.1\% v/v OPA: acetonitrile: methanol } \\
(300: 400: 300 \mathrm{v} / \mathrm{v} / \mathrm{v})\end{array}$ & $\begin{array}{l}\text { ACQUITY UPLC Phenyl } 150 \\
\mathrm{~mm} \times 2.1 \mathrm{~mm} 1.7 \mu \mathrm{m}\end{array}$ & Impurities are not well separated from fulvestrant & $\begin{array}{l}\text { Method } \\
\text { rejected }\end{array}$ \\
\hline 5 & $\begin{array}{l}0.1 \% \mathrm{v} / \mathrm{v} \text { OPA: acetonitrile and } \\
\text { methanol }(300 ; 400 ; 300 \mathrm{v} / \mathrm{v} / \mathrm{v})\end{array}$ & $\begin{array}{l}\text { BEH shield RP18, } 50 \mathrm{~mm} \times \\
2.1 \mathrm{~mm} 1.7 \mu \mathrm{m}\end{array}$ & $\begin{array}{l}\text { Impurities are well separated from fulvestrant with } \\
\text { good peak shape and less run time }\end{array}$ & Approved \\
\hline
\end{tabular}




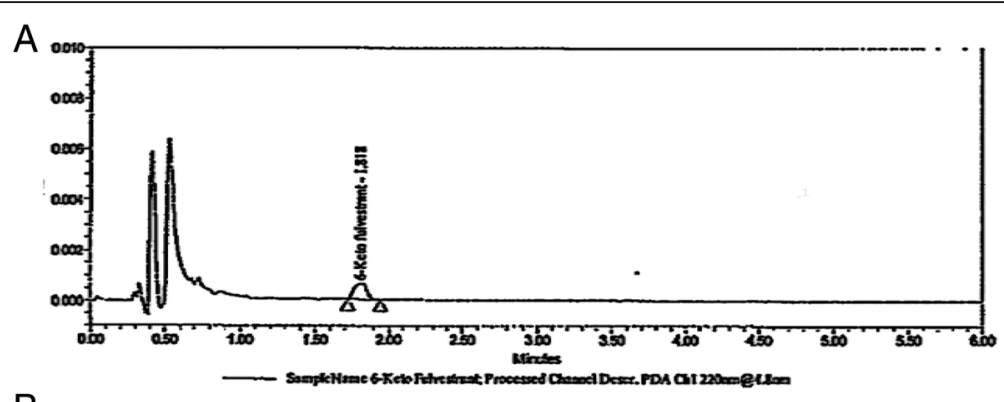

B

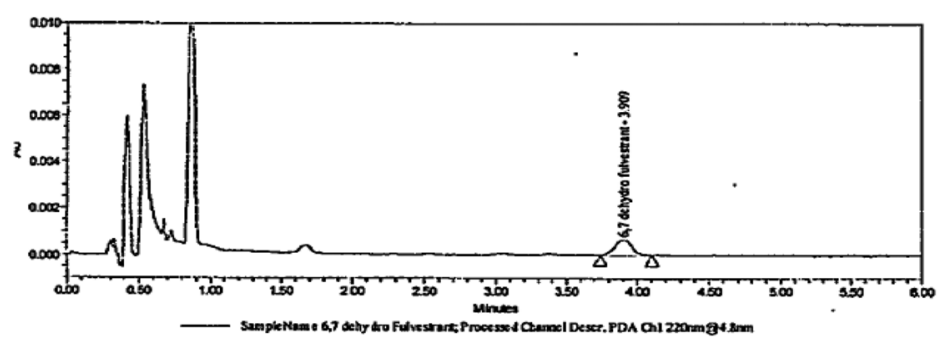

C

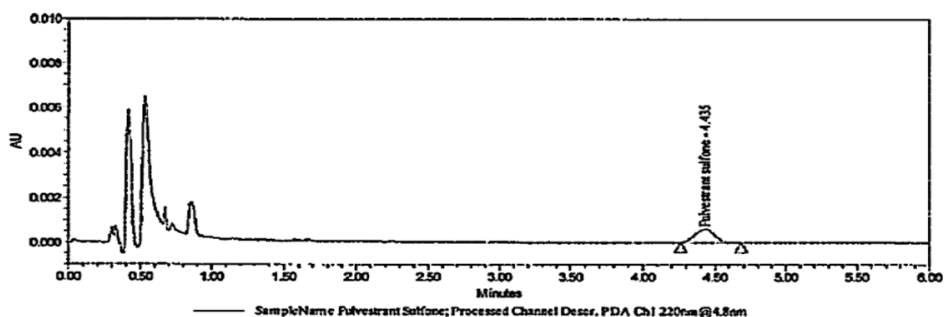

D

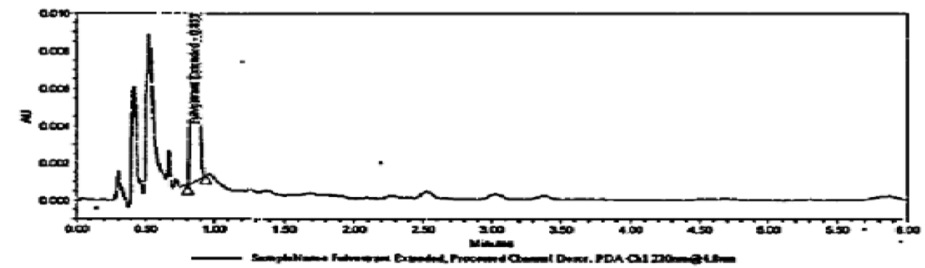

E

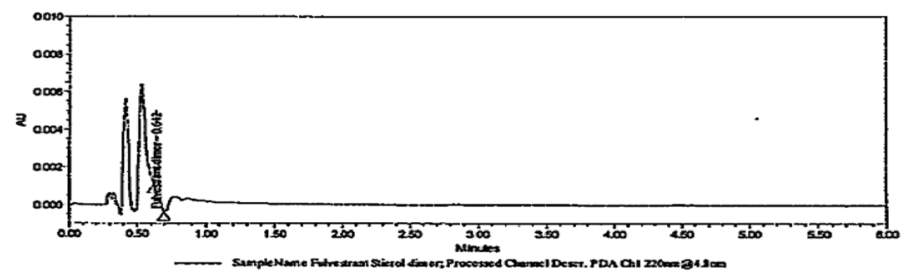

$\mathrm{F}$

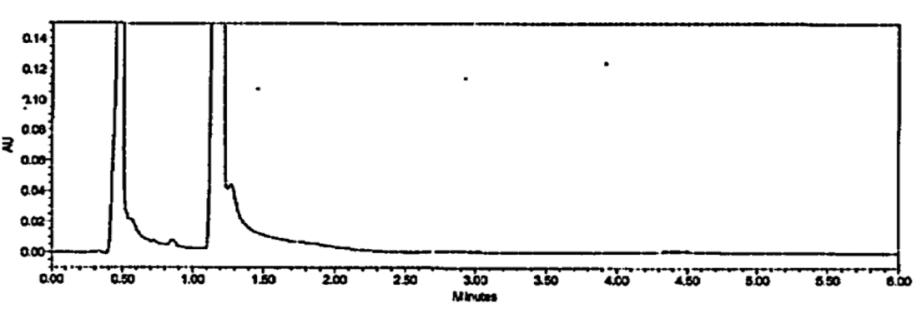

Fig. 4 a 6-Keto fulvestrant $\left(1 \mu \mathrm{gL}^{-1}\right)$. b Delta 6,7-fulvestrant $\left(1 \mu \mathrm{g} \mathrm{mL}{ }^{-1}\right)$. c Fulvestrant 9-sulfone $\left(1 \mu \mathrm{g} \mathrm{mL}^{-1}\right)$. d Fulvestrant extended (1 $\left.\mu \mathrm{g} \mathrm{mL} \mathrm{L}^{-1}\right)$. e Fulvestrant dimer $\left(1 \mathrm{\mu g} \mathrm{mL}^{-1}\right)$. f Fulvestrant sample placebo 


\section{System suitability}

The system suitability test was performed before starting every validation parameter by injecting the $100 \mu \mathrm{g} \mathrm{mL}-1$ of fulvestrant solution for estimation of the assay methods Fig. 2 a Overlaid chromatogram of fulvestrant standard and sample.

\section{Specificity}

The specificity of the method was determined by the preparation of blank, placebo solution and individual impurities of fulvestrant at the known concentration, then subjected to the UPLC-PDA analysis. In addition to the conducted FD studies ("Forced degradation" section), placebo was also evaluated under the same conditions. Peak purity verified for the fulvestrant by using the Empower 3 software. Impurity chromatograms are shown in Fig. 3.

\section{Precision}

The precision of the test method was performed by injection of six independent preparations of the fulvestrant sample at a concentration of $100 \mu \mathrm{g} \mathrm{mL}^{-1}$ and evaluated against the working standard. The \% RSD of the assay method was calculated. The ruggedness of the method was evaluated using two different analysts and two different UPLC systems on two different days.

\section{Linearity}

The linearity of the developed method of fulvestrant was established by analyzing a series of five known concentration levels ranging from 80 to $120 \mu \mathrm{g} \mathrm{mL}^{-1}$. The calibration curves were prepared by plotting the peak areas of the fulvestrant against their respective concentrations. The correlation coefficients $\left(r^{2}\right)$, slopes, and $y$-intercepts of fulvestrant were calculated from their respective calibration plots.

Detection limit (LOD) and quantification limit (LOQ) The LOD and LOQ values for fulvestrant assay were determined by the calibration curve method. LOD and LOQ were calculated by using the following formula.

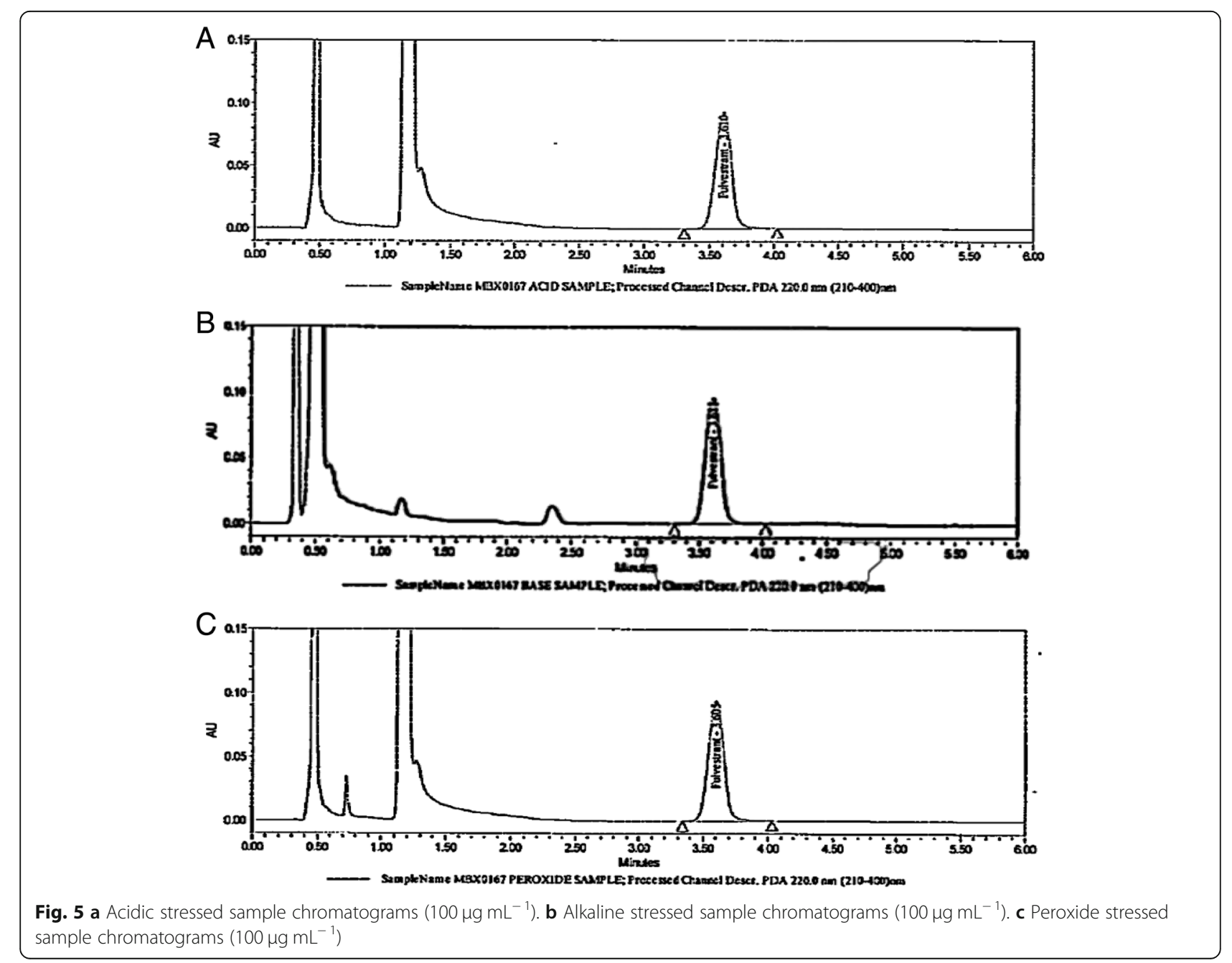




$$
\begin{aligned}
& \text { LOD }=\frac{3.3 \times \text { SD of } y \text {-intercept }}{\text { Slope of a calibration curve }} \\
& \text { LOQ }=\frac{10 \times \text { SD of } y \text {-intercept }}{\text { Slope of a calibration curve }}
\end{aligned}
$$

\section{Accuracy}

The accuracy of the method was determined in triplicate at three concentration levels $\left(50,100\right.$, and $150 \mu \mathrm{g} \mathrm{mL}^{-1}$ ) by adding the standard to the placebo solutions. The percentage of the recovered amounts was calculated.

\section{Robustness}

To determine the robustness of the developed method, chromatographic conditions were deliberately altered and the USP tailing factor, plate count, and \% RSD were assessed.

The flow rate of the mobile phase was changed to 0.24 and $0.36 \mathrm{~mL} / \mathrm{min}$, the column temperature was verified at $30^{\circ} \mathrm{C}$, and the effect of the \% organic strength was studied by altering acetonitrile and methanol. Only one parameter was changed while the other conditions kept constant.

\section{Results}

\section{Optimization of chromatographic conditions}

The main aim of the chromatographic method was to develop a stability-indicating UPLC method for the determination of fulvestrant from its degradation products and placebo peaks in the sample (Fasalodex $250 \mathrm{mg} 5$ $\mathrm{mL}^{-1}$ ) with a short run time between 5 and $6 \mathrm{~min}$. The fulvestrant injection has more than $70 \%$ of castor oil; hence, extraction of fulvestrant and separation from placebo peaks and impurities are the major challenges. The mobile phase and column stationary phases have an important role on peak shape, symmetry (tailing), and resolution from the degradation products. To obtain an optimum resolution, symmetrical peak shape, theoretical plates, and peak purity different chromatographic conditions were verified and optimized for the determination of fulvestrant in the oil phase (refer to Table 1). The mobile phase was tested (sodium phosphate buffer,

Table 3 System suitability results

\begin{tabular}{lll}
\hline S. No. & Name of the parameter & $\begin{array}{l}\text { Observed } \\
\text { value }\end{array}$ \\
\hline 1 & $\begin{array}{l}\text { The USP tailing factor of fulvestrant, peak from } \\
\text { standard chromatogram }\end{array}$ & 1.0 \\
2 & $\begin{array}{l}\text { \% RSD for peak area of fulvestrant for five replicate } \\
\text { injections }\end{array}$ & 0.2 \\
3 & $\begin{array}{l}\text { The USP theoretical plates of fulvestrant peak from } \\
\text { standard chromatogram }\end{array}$ & 4786 \\
\hline
\end{tabular}

\begin{tabular}{|c|c|c|c|c|c|c|}
\hline Component & $\begin{array}{l}\text { Sample } \\
\text { no. }\end{array}$ & $\begin{array}{l}\% \\
\text { Assay }\end{array}$ & $\begin{array}{l}\text { Mean } \\
\% \\
\text { assay }\end{array}$ & $\begin{array}{l}\text { \% } \\
\text { RSD }\end{array}$ & $\begin{array}{l}95 \% \\
\text { confidence } \\
\text { interval }\end{array}$ & $\begin{array}{l}\text { \% RSD of } \\
12 \\
\text { preparations }\end{array}$ \\
\hline \multirow{6}{*}{$\begin{array}{l}\text { Fulvestrant } \\
\text { (intermediate } \\
\text { precision) }\end{array}$} & 1 & 100.4 & \multirow[t]{6}{*}{100.0} & \multirow[t]{6}{*}{0.3} & \multirow{6}{*}{$\begin{array}{l}99.2 \text { and } \\
100.2\end{array}$} & \multirow[t]{12}{*}{0.4} \\
\hline & 2 & 100.0 & & & & \\
\hline & 3 & 99.8 & & & & \\
\hline & 4 & 99.7 & & & & \\
\hline & 5 & 100.2 & & & & \\
\hline & 6 & 99.8 & & & & \\
\hline \multirow{6}{*}{$\begin{array}{l}\text { Fulvestrant } \\
\text { (precision) }\end{array}$} & 1 & 99.6 & \multirow[t]{6}{*}{99.7} & \multirow[t]{6}{*}{0.5} & \multirow{6}{*}{$\begin{array}{l}99.3 \text { and } \\
100.1\end{array}$} & \\
\hline & 2 & 99.9 & & & & \\
\hline & 3 & 98.9 & & & & \\
\hline & 4 & 99.6 & & & & \\
\hline & 5 & 100.4 & & & & \\
\hline & 6 & 100.0 & & & & \\
\hline
\end{tabular}

Table 4 Precision and intermediate precision results

triethylamine $0.1 \%(v / v)$, orthophosphoric acid $0.1 \%(v / v)$ buffer, acetonitrile, and methanol). Different stationary phases were tested for chromatographic separation, such as ACQUITY UPLC HSST3, ACQUITY Phenyl, and ACQUITY BEH shield RP18. In these studies, the decision was based on the optimum resolution between the

\begin{tabular}{|c|c|c|c|c|}
\hline$\%$ Level & $\begin{array}{l}\text { Concentration } \\
\text { (ppm) }\end{array}$ & Area & $\begin{array}{l}\text { Average } \\
\text { area }\end{array}$ & $\begin{array}{l}\% \\
\mathrm{RSD}\end{array}$ \\
\hline $80 \%-1$ & 79.8540 & 657,899 & 659,836 & 0.2 \\
\hline $80 \%-2$ & 79.8540 & 660,890 & & \\
\hline $80 \%-3$ & 79.8540 & 659,817 & & \\
\hline $90 \%-1$ & 89.8357 & 742,007 & 741,004 & 0.1 \\
\hline $90 \%-2$ & 89.8357 & 740,886 & & \\
\hline $90 \%-3$ & 89.8357 & 740,119 & & \\
\hline $100 \%-1$ & 99.8175 & 824,818 & 824,416 & 0.1 \\
\hline $100 \%-2$ & 99.8175 & 824,942 & & \\
\hline $100 \%-3$ & 99.8175 & 823,487 & & \\
\hline 110\%-1 & 109.7992 & 910,473 & 909,937 & 0.1 \\
\hline $110 \%-2$ & 109.7992 & 910,860 & & \\
\hline $110 \%-3$ & 109.7992 & 908,479 & & \\
\hline $120 \%-1$ & 119.7810 & 992,290 & 993,041 & 0.3 \\
\hline $120 \%-2$ & 119.7810 & 990,134 & & \\
\hline $120 \%-3$ & 119.7810 & 996,701 & & \\
\hline $\begin{array}{l}\text { Correlation } \\
\text { coefficient }\end{array}$ & 0.9999 & & & \\
\hline Intercept & -9696.0344 & & & \\
\hline Slope & 8368.7029 & & & \\
\hline Bias at $100 \%$ & -1.18 & & & \\
\hline Standard error & 1291.356784 & & & \\
\hline
\end{tabular}

Table $\mathbf{5}$ Linearity of detector response of fulvestrant 
fulvestrant, its known impurities, and all possible forced degradation peaks generated during different FD conditions. The optimum resolution between the all known peaks and forced degradation products within the short run time was obtained using the BEH shield RP18, 50 $\mathrm{mm} \times 2.1 \mathrm{~mm}, 1.7-\mu \mathrm{m}$ column. Other columns showed inadequate separation in the forced degradation samples. Particularly, the HSST3 column in the oxidative degradation fulvestrant sulfone impurity was not well separated from the main peak. In the phenyl column, the elution of some of the impurities is very long due to the polarity nature that resulted in a long run time. Several mobile phase mixtures were verified using various proportions of different aqueous phases and organic phases. The best chromatographic separation was obtained using an isocratic elution of the mobile phase which contains $0.1 \%$ $w / v$ orthophosphoric acid, methanol, and acetonitrile. During the optimization trials, methanol was used as an organic modifier to separate the fulvestrant impurities (beta isomer and sterol dimer).
A solvent mixture of purified water, acetonitrile, and methanol in the ratio of 300:400:300 then $0.1 \% w / v$ orthophosphoric acid to the solvent mixture was used as a final composition. It resulted in chromatograms with optimum resolution, and good peak shape was shown for the fulvestrant. The DAD detector offers the advantage of measuring the maximum wavelength of each peak in addition to peak purity of stressed samples. The PDA detector enhances the power of UPLC, and it is an effective tool to assess the specificity by the quantification of recorded chromatograms during the elution of peaks. Fulvestrant has a short UV region (below 225), i.e., $220 \mathrm{~nm}$, and an optimum UV region (above 254), i.e., $280 \mathrm{~nm}$. Fulvestrant has stronger UV absorption at $220 \mathrm{~nm}$; hence, the wavelength of $220 \mathrm{~nm}$ was selected for recording the chromatograms. The optimized chromatographic conditions have shown symmetric peaks and good resolution between the peaks in the stressed samples. System suitability parameters were calculated for the fulvestrant standard peak and were found satisfactory.
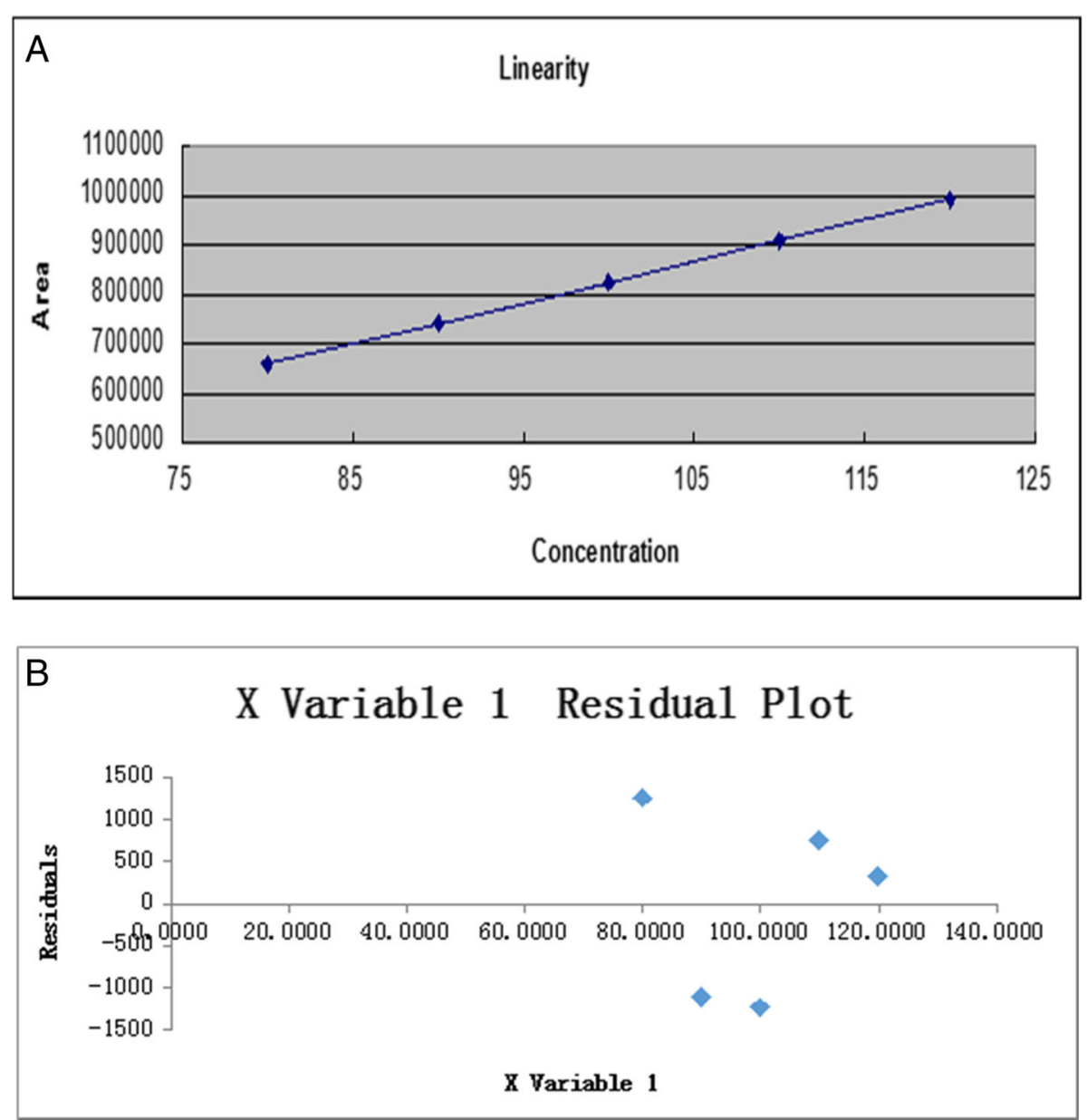

Fig. 6 a Linearity graph of fulvestrant from $80 \mu \mathrm{gL}^{-1}$ to $120 \mu \mathrm{g} \mathrm{mL}-1$. b Residuals for of detector response of fulvestrant 


\section{Stability-indicating assessment}

FD experiments were performed on fulvestrant injection sample to produce the possible relevant degradation products in the presence of placebo and to test their chromatographic nature using the developed method. The percent of degradation depends upon the concentration of reagents, time of stress, and exposed temperatures. Generally, the percent of degradation of drug product between 5 and 20\% has been accepted. Therefore, the sample was exposed to optimum conditions to achieve the target concentration (refer "Preparation of standard" section for FD conditions). All the experiments were conducted, and the chromatograms were recorded and were compared with those obtained from standard untreated solutions.

Peak purity was verified for all the stressed sample chromatograms by using the PDA detector. Peak purity of the stressed samples was verified by using the empower 3 software. It is the weighted average of all spectral contrast angle calculated by comparing the spectra from all data points in the integrated peak against the peak apex spectrum. The peak that shows the purity angle less than the purity threshold can be considered as peak purity passed, i.e., no other peaks co-eluted with that peak. If the purity angle is greater than the purity threshold, there is something within the peak so that we can consider the peak is not pure. The obtained purity angle and purity threshold limits confirm that peaks are pure and homogenous in all stressed conditions. Data are shown in Table 2 and Figs. 4 and 5.

Table 6 Accuracy

\begin{tabular}{|c|c|c|c|c|c|c|}
\hline $\begin{array}{l}\text { S. } \\
\text { No. }\end{array}$ & $\begin{array}{l}\text { Spike } \\
\text { level }\end{array}$ & $\begin{array}{l}\text { "mg" } \\
\text { added }\end{array}$ & $\begin{array}{l}\text { "mg" } \\
\text { found }\end{array}$ & $\begin{array}{l}\% \\
\text { recovery }\end{array}$ & $\begin{array}{l}\text { Average \% } \\
\text { recovery }\end{array}$ & $\begin{array}{l}\% \\
\text { RSD }\end{array}$ \\
\hline 1 & 80\%-1 & 40.01 & 40.0900 & 100.2 & 100.1 & 0.3 \\
\hline 2 & $80 \%-2$ & 40.00 & 40.0400 & 100.1 & & \\
\hline 3 & $80 \%-3$ & 40.00 & 40.2000 & 100.5 & & \\
\hline 4 & $80 \%-4$ & 40.06 & 40.2202 & 100.4 & & \\
\hline 5 & $80 \%-5$ & 39.99 & 39.8300 & 99.6 & & \\
\hline 6 & $80 \%-6$ & 40.03 & 40.0700 & 100.1 & & \\
\hline 7 & 100\%-1 & 49.86 & 49.9597 & 100.2 & 100.4 & 0.2 \\
\hline 8 & $100 \%-2$ & 49.82 & 50.0691 & 100.5 & & \\
\hline 9 & $100 \%-3$ & 49.83 & 50.0293 & 100.4 & & \\
\hline 10 & 120\%-1 & 60.69 & 60.6293 & 99.9 & 99.7 & 0.2 \\
\hline 11 & $120 \%-2$ & 60.74 & 60.6185 & 99.8 & & \\
\hline 12 & $120 \%-3$ & 60.71 & 60.4065 & 99.5 & & \\
\hline 13 & $120 \%-4$ & 60.70 & 60.4572 & 99.6 & & \\
\hline 14 & $120 \%-5$ & 60.73 & 60.3049 & 99.3 & & \\
\hline 15 & $120 \%-6$ & 60.63 & 60.5694 & 99.9 & & \\
\hline
\end{tabular}

Table 7 Results of effect of variation in flow rate

\begin{tabular}{|c|c|c|c|c|}
\hline S. No. & Name of the parameter & $\begin{array}{l}0.3 \mathrm{~mL} \\
\mathrm{~min}^{-1}\end{array}$ & $\begin{array}{l}0.24 \mathrm{~mL} \\
\mathrm{~min}^{-1}\end{array}$ & $\begin{array}{l}0.36 \mathrm{~mL} \\
\mathrm{~min}^{-1}\end{array}$ \\
\hline 1 & Tailing factor for fulvestrant peak & 0.94 & 0.93 & 0.97 \\
\hline 2 & $\begin{array}{l}\% \text { RSD of fulvestrant peak areas for } \\
\text { five replicate injections of standard }\end{array}$ & 0.1 & 0.1 & 0.1 \\
\hline 3 & $\begin{array}{l}\text { USP plate count for fulvestrant } \\
\text { peak }\end{array}$ & 4013 & 4054 & 3970 \\
\hline 4 & $\%$ Assay & 99.3 & 101.4 & 99.5 \\
\hline
\end{tabular}

\section{System suitability}

System suitability is used to asses that the UPLC system and columns were giving the adequate reproducibility, tailing factor, theoretical plates, RT (retention time), and repeatability as \% RSD of the peak area of six replicate injections of fulvestrant standard solution $100 \mu \mathrm{g} \mathrm{mL}^{-1}$. The tailing factor showed less than 1.5, and the theoretical plates were more than 2500 . The $\%$ RSD of the peak area was 0.2 .

Data are shown in Table 3.

\section{Precision}

The repeatability of the test method was determined by preparing six determinations of the concentration $100 \mu \mathrm{g} \mathrm{mL}^{-1}$ (representing 100\%). The ruggedness of the method was carried out by the different system, column, and day. The \% RSD of fulvestrant during the repeatability and intermediate precision (ruggedness) was $0.5 \%$ and $0.3 \%$, respectively.

Data are shown in Table 4.

\section{Linearity}

The linearity for the PDA detector was determined in the concentration range $80-120 \mu \mathrm{g} \mathrm{mL}^{-1}$ for fulvestrant. The calibration curve was established with concentration against the peak area. The regression equitation for the calibration curve was found to be $y=8368.7029 x+$ 9696.0344, and the $r^{2}$ of 0.9999 was obtained.

Data are shown in Table 5 and Fig. 6.

\section{Detection limit (LOD) and quantification limit (LOQ)}

The limit of detection (LOD) and limit of quantification (LOQ) of fulvestrant were established by the slope method. Results were found to be $0.51 \mu \mathrm{g} \mathrm{mL}^{-1}$ and $1.54 \mu \mathrm{g} \mathrm{mL}^{-1}$, respectively.

Table 8 Results of effect of variation in column temperature

\begin{tabular}{llll}
\hline S. No. & Name of the parameter & $25^{\circ} \mathrm{C}$ & $30^{\circ} \mathrm{C}$ \\
\hline 1 & Tailing factor for fulvestrant peak & 0.93 & 0.94 \\
2 & \% RSD of fulvestrant peak areas for & 0.1 & 0.1 \\
& five replicate injections of standard & & \\
3 & USP plate count for fulvestrant peak & 4013 & 3980 \\
4 & \% Assay & 99.3 & 99.8 \\
\hline
\end{tabular}


Table 9 Results of effect of variation in organic (methanol) variation

\begin{tabular}{lllll}
\hline S. No. & Name of the parameter & $\begin{array}{l}\text { Water:ACN:MeOH } \\
(300: 400: 300)\end{array}$ & $\begin{array}{l}\text { Water:ACN:MeOH } \\
(300: 400: 270)\end{array}$ & $\begin{array}{l}\text { Water:ACN:MeOH } \\
(300: 400: 330)\end{array}$ \\
\hline 1 & Tailing factor for fulvestrant peak & 0.95 & 0.95 & 0.95 \\
2 & $\begin{array}{l}\text { \% RSD of fulvestrant peak areas for five replicate injections } \\
\text { of standard }\end{array}$ & 0.1 & 0.0 & 0.1 \\
3 & $\begin{array}{l}\text { USP plate count for fulvestrant peak } \\
4\end{array} \quad$ \% Assay & 4223 & 4288 & 3796 \\
\hline
\end{tabular}

\section{Accuracy}

The accuracy of the method was verified by performing the recovery study, addition of standard to the placebo at three different concentration levels $(80 \%, 100 \%$, and $120 \%)$. The percent recoveries for fulvestrant were found to be 100.1, 100.4, and 99.7 respectively.

Data are shown in Table 6.

\section{Robustness}

To determine the robustness of the developed method, chromatographic conditions were deliberately altered, and in all the varied chromatographic conditions (flow rate, column temperature, and compositions of organic solvents), no significant changes were observed in the system suitability parameters. Data are shown in Tables 7, 8, 9, and 10.

\section{Stabilities}

Stability of the drug substance and drug product was conducted at different conditions for quality control (QC) of samples. The assay is compared with freshly analyzed QC samples; no difference was found in percent of assay. So, no degradation of the product was observed while performing the analysis.

\section{Discussion}

The UPLC procedure was carried out to develop a stability-indicating method for quantification of fulvestrant. The major challenges faced in the current study were as follows: the resolution between the impurities and fulvestrant peak with less run time, selection of an appropriate mobile phase composition with an isocratic method to obtain optimum resolution between the impurity peaks, optimization of the test concentration to get the desired LOQ levels for the fulvestrant, and the low LOD and LOQ values indicating the method sensitivity. In addition, the UPLC method can be considered specific, where it can be used for drug substance separation and quantification of drug product from its degradation products and placebo peaks.

Method validation was performed as per the $\mathrm{ICH}$ guidelines. The linearity of the proposed UPLC method was performed. Linear relationships between concentration and high regression coefficients were obtained. Intra-day and inter-day precision was also evaluated. In addition, good results in terms of LOD, LOQ, robustness, and selectivity were obtained.

\section{Conclusion}

The current paper shows an accurate, specific, and reproducible stability-indicating RP-UPLC assay method developed and validated for the quantification of fulvestrant in oil-based injection formulations according to the ICH and USP guidelines. To our best knowledge, no attempts have been made yet to develop a stability-indicating UPLC assay method for the fulvestrant injection. This work shows the stability of the fulvestrant at different stressed conditions. The UPLC method shows good performance with linearity, accuracy, precision, specificity, and robustness. The method has high sensitivity for the fulvestrant, and high-percentage recoveries were obtained by this method. This is the first stability-indicating method developed which has the capability to resolve all the fulvestrant degradation products from the drug substance and drug products.

Table 10 Results of effect of variation in organic (acetonitrile) variation

\begin{tabular}{lllll}
\hline S. No. & Name of the parameter & $\begin{array}{l}\text { Water:ACN:MeOH } \\
(300: 400: 300)\end{array}$ & $\begin{array}{l}\text { Water:ACN:MeOH } \\
(300: 360: 300)\end{array}$ & $\begin{array}{l}\text { Water:ACN:MeOH } \\
(300: 440: 300)\end{array}$ \\
\hline 1 & Tailing factor for fulvestrant peak & 0.94 & 0.94 & 0.95 \\
2 & $\begin{array}{l}\text { \% RSD of fulvestrant peak areas for five replicate injections } \\
\text { of standard }\end{array}$ & 0.2 & 0.1 & 0.3 \\
3 & USP plate count for fulvestrant peak & 4229 & 4263 & 4002 \\
4 & \% Assay & 101.4 & 100.7 & 100.7 \\
\hline
\end{tabular}




\section{Abbreviations}

FD: Forced degradation; LOD: Limit of detection; LOQ: Limit of quantification; PDA: Photodiode array detector; Pfs: Pre-filled syringe; UPLC: Ultraperformance liquid chromatography

\section{Acknowledgements}

The Authors are thankful to Aurex Laboratories Pvt. Ltd, and Aurex Laboratories LLC management for the support.

\section{Funding}

Not applicable

\section{Availability of data and materials}

Research data have been provided in the manuscript.

\section{Authors' contributions}

TD developed the UPLC method and validated, performed the data analysis, reviewed the literature, and drafted the manuscript. AKP supervised the experiment and given inputs in the method development. NK provided guidance for writing and revising the manuscript. $W$ did the manuscript proofreading to respond to the reviewer comments. All authors read and approved the final manuscript.

\section{Ethics approval and consent to participate}

Not applicable

\section{Consent for publication}

Not applicable

\section{Competing interests}

The authors declare that they have no competing interests.

\section{Publisher's Note}

Springer Nature remains neutral with regard to jurisdictional claims in published maps and institutional affiliations.

\section{Author details}

${ }^{1}$ Aurex Laboratories LLC, 10 Lake drive, Eastwindsor, NJ 08520, USA. 2Department of Chemistry, GITAM University, Hyderabad, Telangana 502329, India.

Received: 12 November 2018 Accepted: 17 February 2019

Published online: 14 March 2019

\section{References}

Addo S, Yates RA, Laight A. A phase I trial to assess the pharmacology of the new estrogen receptor antagonist fulvestrant on the endometrium in healthy post-menopausal volunteers. Br J Cancer. 2002:87(12):1354-9.

Bogliolo S, Gardella B, Dominoni M. Effectiveness of aromatase inhibitors in the treatment of advanced endometrial adenocarcinoma. Arch Gynecol Obstet. 2016;293(4):701-8.

Bowler J, Lilley TJ, Pittam JD, Wakeling AE. Novel steroidal pure antiestrogens. Steroids. 1989:54(1):71-99.

Bross PF, Cohen MH, Williams GA, Pazdur R. FDA drug approval summaries: fulvestrant. Oncologist. 2002;7(6):477-80.

Brunner D, Oellers N, Szabad J, Biggs WH, Zipursky SL, Hafen E. A gain-of-function mutation in Drosophila MAP kinase activates multiple receptor tyrosine kinase signaling pathways. Cell. 1994;76(5):875-88.

Bundred N, Howell A. Fulvestrant (Faslodex): current status in the therapy of breast cancer. Expert Rev Anticancer Ther. 2002;2(2):151-60. https://doi.org/ 10.1586/14737140.2.2.151.

Buzdar AU, Robertson JF. Fulvestrant: pharmacologic profile versus existing endocrine agents for the treatment of breast cancer. Ann Pharmacother. 2006:40:1572-83

Di Leo A, Jerusalem G, Petruzelka L. Results of the CONFIRM phase III trial comparing fulvestrant $250 \mathrm{mg}$ with fulvestrant $500 \mathrm{mg}$ in postmenopausal women with estrogen receptor-positive advanced breast cancer. J Clin Oncol. 2010;28(30):4594-600

Dodwell D, Vergote I. A comparison of fulvestrant and the third-generation aromatase inhibitors in the second-line treatment of postmenopausal women with advanced breast cancer. Cancer Treat Rev. 2005;31:274-82.
Harrison M, Laight A, Clarke DA. Pharmacokinetics and metabolism of fulvestrant after oral, intravenous and intramuscular administration in healthy volunteers. In: Proc ASCO 22;45 abstract 311; 2003.

$\mathrm{ICH}$, Stability testing of new drug substances and products. Validation of analytical procedures: text and methodology. In: In: 449 proceedings of the international conference on harmonization; 2005.

$\mathrm{ICH}$, Stability testing of new drug substances and products, Q1A (R2). International conference on harmonization of technical requirements for registration of pharmaceuticals for human use. Geneva: IFPMA; 2003.

Morris C, Wakeling A. Fulvestrant ("Faslodex")—A New Treatment Option for Patients Progressing on Prior Endocrine Therapy. Endocrine-Related Cancer. 2002;9:267-76. https://doi.org/10.1677/erc.0.0090267.

Osborne CK, Wakeling A, Nicholson RI. Fulvestrant: an estrogen receptor antagonist with a novel mechanism of action. Br J Cancer. 2004;90(Suppl.1): \$2-6.

Robertson IH, Ward T, Ridgeway V, Nimmo-Smith I. The structure of normal human attention: The Test of Everyday Attention. J Int Neuropsychol Soc. 1996;2(6):525-34.

Robertson JFR, Erikstein B, Osborne CK. Pharmacokinetic profile of intramuscular fulvestrant in advanced breast cancer. Clin Pharmacokinet. 2003:43(8):529-38.

Robertson JFR, Harrison M. Fulvestrant: pharmacokinetics and pharmacology. Br Cancer Mar. 2004:90(Suppl 1):S7-S10.

Varanasi MB, Dharmesh P, Bulusu BT, Shivprakash R, Jangala VR, Bhavesh D. Sensitive and rapid high-performance liquid chromatography tandem mass spectrometry method for estimation of fulvestrant in rabbit plasma. Biomed Chromatogr. 2010;24:863-7.

Vergote I, Abram P. Fulvestrant, a new treatment option for advanced breast cancer: tolerability versus existing agents. Ann Oncol. 2006;17:200-4.

Wakeling AE. The future of new pure antioestrogens in clinical breast cancer. Breast Cancer Rese Treat. 1993;25:1-9.

\section{Submit your manuscript to a SpringerOpen ${ }^{\circ}$ journal and benefit from:}

- Convenient online submission

- Rigorous peer review

- Open access: articles freely available online

High visibility within the field

- Retaining the copyright to your article

Submit your next manuscript at $\boldsymbol{\nabla}$ springeropen.com 